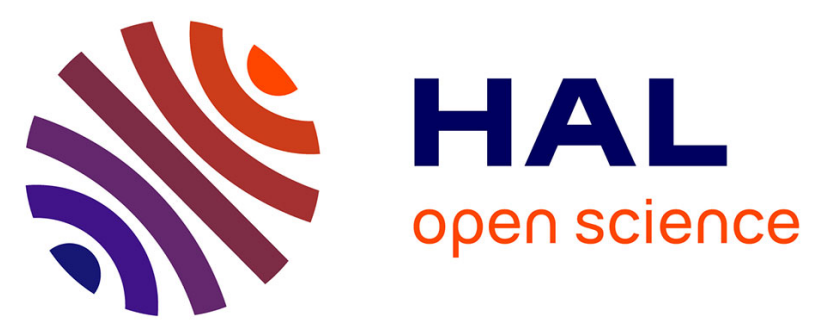

\title{
Prediction of dose-hepatotoxic response in humans based on toxicokinetic/toxicodynamic modeling with or without in vivo data: A case study with acetaminophen
}

Alexandre R.R. Pery, Céline Brochot, Florence Anna Zeman, Enrico Mombelli, Sophie Desmots, Manuela Pavan, Elena Fioravanzo, José-Manuel Zaldivar

\section{To cite this version:}

Alexandre R.R. Pery, Céline Brochot, Florence Anna Zeman, Enrico Mombelli, Sophie Desmots, et al.. Prediction of dose-hepatotoxic response in humans based on toxicokinetic/toxicodynamic modeling with or without in vivo data: A case study with acetaminophen. Toxicology Letters, 2013, 220 (1), pp.26-34. 10.1016/j.toxlet.2013.03.032 . ineris-00961804

\section{HAL Id: ineris-00961804}

https://hal-ineris.archives-ouvertes.fr/ineris-00961804

Submitted on 20 Mar 2014

HAL is a multi-disciplinary open access archive for the deposit and dissemination of scientific research documents, whether they are published or not. The documents may come from teaching and research institutions in France or abroad, or from public or private research centers.
L'archive ouverte pluridisciplinaire HAL, est destinée au dépôt et à la diffusion de documents scientifiques de niveau recherche, publiés ou non, émanant des établissements d'enseignement et de recherche français ou étrangers, des laboratoires publics ou privés. 


\section{Prediction of dose - hepatotoxic response in humans based on toxicokinetic/toxicodynamic modeling with or without in vivo data: A case study with acetaminophen}

Alexandre R.R. Péry ${ }^{\mathrm{a},}$, ,éline Brochot ${ }^{\mathrm{a}}$, Florence A. Zeman ${ }^{\mathrm{a}}$, Enrico Mombelli ${ }^{\mathrm{a}}$, Sophie Desmots $^{\mathrm{b}}$, Manuela Pavan ${ }^{\mathrm{c}}$, Elena Fioravanzo ${ }^{\mathrm{c}}$, José-Manuel Zaldívar ${ }^{\mathrm{d}}$

${ }^{\text {a } U n i t e ́ ~ « ~ M o d e ̀ l e s ~ p o u r ~ l ' e ́ c o t o x i c o l o g i e ~ e t ~ l a ~ t o x i c o l o g i e ~ » ~(M E T O), ~ I N E R I S, ~ p a r c ~ A l a t a ~}$ BP2, 60550 Verneuil-en-Halatte, France.

${ }^{\mathrm{b}}$ Unité « Toxicologie expérimentale» (TOXI), INERIS, parc Alata BP2, 60550 Verneuil-enHalatte, France.

${ }^{c}$ S-IN Soluzioni Informatiche, Via Ferrari 14, 36100 Vicenza, Italy.

${ }^{\mathrm{d}}$ European Commission, Joint Research Centre, Ispra, Italy.

* Corresponding author at: INERIS, parc Alata BP2, 60550 Verneuil-en-Halatte, France. Tel: +33 3445561 26. E-mail adress: alexandre.pery@ineris.fr. 


\begin{abstract}
In the present legislations, the use of methods alternative to animal testing is explicitly encouraged, to use animal testing only 'as a last resort' or to ban it. The use of alternative methods to replace kinetics or repeated dose in vivo tests is a challenging issue. We propose here a strategy based on in vitro tests and QSAR (Quantitative Structure Activity Relationship) models to calibrate a dose-response model predicting hepatotoxicity. The dose response consists in calibrating and coupling a PBPK (Physiologically-based pharmacokinetic) model with a toxicodynamic model for cell viability. We applied our strategy to acetaminophen and compared three different ways to calibrate the PBPK model: only with in vitro and in silico methods, using rat data or using all available data including data on humans. Some estimates of kinetic parameters differed substantially among the three calibration processes, but, at the end, the three models were quite comparable in terms of liver toxicity predictions and close to the usual range of human overdose. For the model based on alternative methods, the good adequation with the two other models resulted from an overestimated renal elimination rate which compensated for the underestimation of the metabolism rate. Our study points out that toxicokinetics/toxicodynamics approaches, based on alternative methods and modelling only, can predict in vivo liver toxicity with accuracy comparable to in vivo based methods.
\end{abstract}

Key-words: PBPK, model calibration, liver toxicity, acetaminophen, vitro-vivo extrapolation. 


\section{Introduction}

The promotion of alternative approaches to replace, reduce or refine animal use is present in all relevant EU legislations. For chemicals in general, the REACH legislation requires industry to evaluate the toxicity of new and existing chemicals, even those that are in use but have never been subject to regulatory testing, which translates into many thousands of chemicals to be tested. To fulfil this objective, the legislation explicitly encourages the use of methods alternative to animal testing, which would only be used 'as a last resort'. As far as cosmetics are concerned, the 7th Amendment to the Cosmetic Directive (76/768/EEC) was adopted in 2003. According to this directive, animal testing in the EU for cosmetic products had to stop immediately and a complete ban of animal testing for ingredients was due to enter into force by 11 March 2009. The deadline for most complex endpoints such as repeated dose toxicity, reproductive toxicity and toxicokinetics was set for the 11th of March 2013 but the directive can also accommodate an extension if alternative and validated methods are not available within this time framework. In parallel to the set up of a new legislation, considerable efforts, in particular from EU, were made to develop suitable and appropriate alternative methods. For instance, between 2003 and 2010, European Commission funded research programmes related to such development through FP6 and FP7 programmes for around 150 million euros (Adler et al., 2011).

Most of the toxicological information for a chemical obtained through in vitro testing provides information on the dose response relationship at target cell or, more rarely, at target organ level. Future risk assessment is expected to focus on avoiding significant perturbations in toxicity pathways through in vitro assays on human cells or cell lines (Krewski et al., 2010). To integrate the in vitro results into quantitative in vivo risk assessment, it is thus necessary to relate the toxicokinetics (TK) of the chemical in the body and the toxicodynamics at each target level (Andersen and Krewski, 2010 ; Adler et al., 2011 ; Louisse et al., 2012 ; Yoon et al., 2012). This can be achieved through Physiologically Based Toxicokinetics or Pharmacokinetics models - PBTK or PBPK- (Clewell et al., 2008). A PBTK model consists of a series of mathematical equations which, based on the specific physiology of an organism and on the physicochemical properties of a substance, are able to describe the absorption, distribution, metabolism and elimination (ADME) of the compound within this organism. The solution of these equations provides the time-course of the parent 
compound and its metabolites in the organs and allows for a sound mechanistic description of the kinetic processes including accumulation in tissues.

There are only a few examples for which PBPK models were used to extrapolate in vitro response to in vivo hazard assessment. Rotroff et al. (2010) combined a simple PBPK model with in vitro bioactivity data to rank chemicals according to actual human oral exposure and oral exposure leading to significant activity. As for tentative to go a step further in the prediction, Péry et al. (2011) showed the possibility to relate in vitro and in vivo gene responses in macrophages following exposure to benzo(a)pyrene through PBPK modeling. Punt et al. (2011) proposed a few examples where PBPK models have been used to extrapolate in vitro toxicity results to the in vivo situation. They show that predictions of in vivo effects on the basis of integrated in vitro and PBPK modeling approaches are generally within one order of magnitude of the observed in vivo data. Among the examples, Gubbels van-Hal et al. (2005) attempted to predict acute toxicity and repeated dose toxicity based on PBPK models and cytotoxic data. In general, the predictions over-estimated the toxicity, which could be both due to overestimation of the effects in the in vitro systems and uncertainty on the toxicokinetics parameters. There are thus improvements to be made both in the experimental field and in the accurate calibration of toxicokinetics models. Punt et al. (2011) asked for more examples that provide proof of principle of deriving in vivo doseresponse curves based on in vitro assays and PBPK modeling techniques. Yoon et al. (2012) reviewed different quantitative in vitro to in vivo extrapolations (QIVIVE). They identified key elements that have to be predicted for a successful extrapolation: (i) intestinal absorption and pre-hepatic clearance, (ii) hepatic and extra-hepatic metabolic clearance, (iii) renal clearance, (iv) volume of distribution (for acute in vivo exposures). They also indicated that only rare examples of QIVIVE do not rely, at least partly, on in vivo data.

In this paper, we propose a modeling framework to predict in vivo liver toxicity. The proposed framework is composed by a dynamic model to analyse in vitro concentration-liver cell viability data throughout time, and by a PBPK model to relate dose of exposure and concentration in the liver. As case study, this modeling framework was applied to humans exposed to acetaminophen, which is a pharmaceutical known for its hepatotoxicity (Jaeschke et al., 2011). The human PBPK model was calibrated in three different ways: i. with in vitro and in silico methods only, ii. by extrapolating to humans a PBPK model calibrated for rats, as usually performed in human toxicokinetics assessment based on animal testing, iii. or by using all relevant available data, including actual human data to compare the quality of the kinetics and effects predictions based either on animal or non-animal testing. 


\section{Materials and methods}

\subsection{Toxicokinetic data in rats for acetaminophen}

Male Sprague-Dawley rats were purchased from Elevage Janvier Laboratory (Le Genet Saint Isle, France). They were maintained under standardized conditions (relative humidity $55 \pm 15 \%, 12$-h day night cycle, room temperature $22 \pm 2^{\circ} \mathrm{C}$ ). There were five different groups of 16 rats, with different times of exposure per group. For each group, 14 rats were orally exposed to a single dose of acetaminophen in an aqueous suspension containing methycellulose $(0,5 \% \mathrm{w} / \mathrm{v})$ and Tween $80(0,1 \% \mathrm{w} / \mathrm{v})$. We selected the dose of $600 \mathrm{mg} / \mathrm{kg}$ which is likely to induce liver damages in some Sprague-Dawley rats after the ingestion of one dose (Clayton et al., 2006). The remaining 2 control rats received vehicle only. The volume of administration was $10 \mathrm{ml} / \mathrm{kg}$ for each animal. Individual blood sample were collected from the retro-orbital sinus under slight isoflurane anaesthesia at 30,60,120, 180 and $240 \mathrm{~min}$, then collected into plastic tubes containing lithium heparin as an anticoagulant and immediately centrifuged ( $17000 \mathrm{~g}$ at $4^{\circ} \mathrm{C}$ during 10 minutes to extract plasma). The urine was collected during the $24 \mathrm{~h}$ post-exposure. Individual post-dose urine samples were collected from each rat into vessels which contained $0,5 \mathrm{ml}$ of a $100 \mathrm{mg} / \mathrm{ml}$ solution of sodium azide in distilled water as an antibacterial preservative and were kept frozen at $-80^{\circ} \mathrm{C}$. The experimental protocol has been approved by the local ethical committee for animal research.

Acetaminophen (APAP) metabolism mainly occurs through sulfation and glucuronidation. A small fraction of the drug undergoes oxidative metabolism via cytochrome P450 and is excreted as acetaminophen mercapturate and acetaminophen cysteine. In rats, at a dose of 320 $\mathrm{mg} / \mathrm{kg}$, one half is excreted as acetaminophen glucuronide (one half in the bile, one half in urine) and one third is excreted in urine as acetaminophen sulfate (Watari et al., 1983). For the dose of concern in our experimental study (600 mg/kg), Hjelle and Klaasen (1984) showed that biliary excretion of APAP and its metabolites reached 49\% (between 20.2 and $29.3 \%$ after 4 hours), most of the compounds in the bile being glucuronide conjugate. Consequently, most of the analytical measurements in our experimental study focused on acetaminophen, acetaminophen glucuronide and acetaminophen sulfate. They were measured in blood and urine by PHATOPHY (Marcy-L'étoile, France) through LC/MS-MS method. In 
addition, acetaminophen mercapturate was measured in urine by the same company with the same analytical method to improve the accuracy of the estimation of the parameters.

\section{2. $\quad$ PBPK modelling of acetaminophen kinetics in rats}

The formation of acetaminophen sulfate in rats is limited by the availability of inorganic sulfate, with a rate of steady-state acetaminophen sulfate formation around $33 \mu \mathrm{mol} / \mathrm{kg} / \mathrm{hour}$ (Galinsky and Levy, 1981), which, in our study, corresponds to $10 \mu \mathrm{mol}$ per hour. For moderate doses of APAP, sulfation capacity rapidly decreases to $20-30 \%$ of normal level (Kim et al., 1992; Liu and Klaassen, 1996). Kim et al. (2009) also showed that 18h after a pretreatment with a dose of APAP of $500 \mathrm{mg} / \mathrm{kg}$, rats still had a deeply depleted capacity of sulfation. In contrast, there is no saturation of the cumulative excretion of the glucuronide conjugate from 37.5 to $600 \mathrm{mg} / \mathrm{kg}$ (Hjelle and Klaasen, 1984). We thus did not account for saturation of glucuronidation but accounted for saturation of sulfation, by introducing both a maximum velocity per $\mu \mathrm{mol}$ of available sulfate and the total quantity of available sulfates.

The rat PBPK model describes the kinetics of acetaminophen, and also of its main metabolites to compare its prediction with data available in the literature. The parameters are listed in Table 1 and a schematic representation available in Figure 1. The equations are the following:

The quantity of $\operatorname{APAP}\left(Q_{\text {APAPgut }}\right)$ in the intestinal tract is described as follows:

$\frac{d Q_{A P A P} \text { gut }}{d t}=$ Frac $_{\text {ing }} * Q_{\text {admin }}-k_{\text {gut }} * Q_{A P A P_{\text {gut }}}$

where $Q_{a d m i n}$ corresponds to total quantity of ingested APAP during the first minute (in $\mu \mathrm{mol}$ ), and set to zero afterwards. Frac $c_{\text {ing }}$ correspond to the fraction of acetaminophen that can enter the liver and $k_{\text {gut }}$ to the oral absorption rate $\left(\mathrm{min}^{-1}\right)$.

In general, kinetics in organ $i$ is described by the equation:

$$
\frac{d C_{i}}{d t} V_{i}=F_{i}\left(C_{b}-\frac{C_{i}}{P C_{i}}\right)
$$

with, in the organ $i, C i$ the concentration (of APAP, sulfate APAP or APAP glucuronide) (in $\mu \mathrm{mol} / \mathrm{L}$ ) and $P C_{i}$ the partition coefficient (of APAP, sulfate APAP or APAP glucuronide), $V_{i}$ 
the volume (in $\mathrm{L}$ ), $F i$ the blood flow (in $\mathrm{L} / \mathrm{min} / \mathrm{kg}$ ), and $C_{b}$ the concentration in blood (in $\mu \mathrm{mol} / \mathrm{L})$. The equations are more complex for liver:

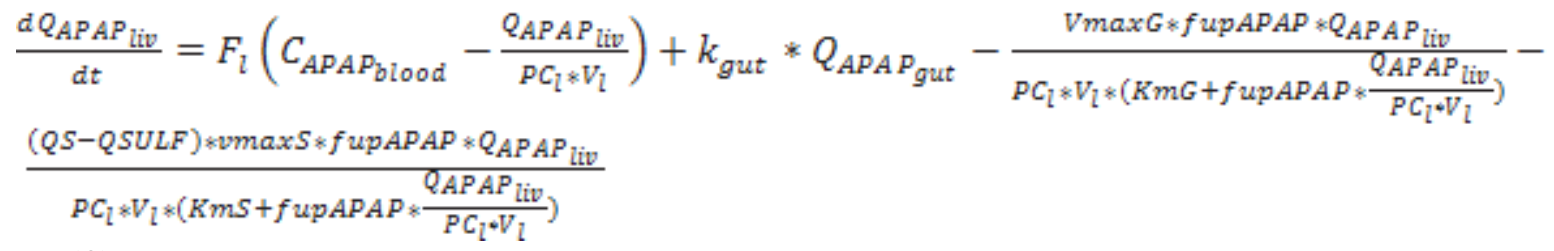

with $Q_{A P A P l i v}$ the total quantity of APAP in the liver, $C_{A P A P b l o o d}$ the concentration of APAP in blood, QSULF the total quantity of sulfate APAP that has been produced (in $\mu$ mol), $Q S$ the maximum value for this quantity (in $\mu \mathrm{mol}$ ), and fup the fraction not bound to proteins. No resynthesis term was needed because the time-frame in the animal is short.

For APAP glucuronide, we have, accounting for biliary excretion:

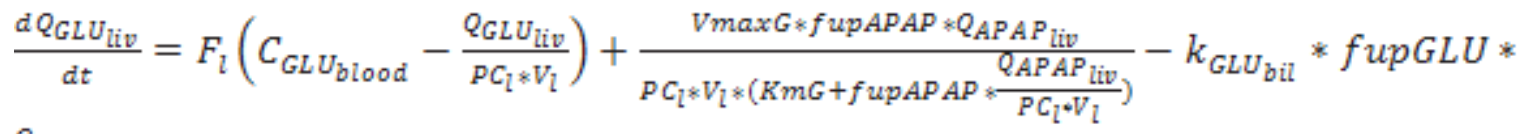
$\frac{Q_{G L U} U_{\text {IIV }}}{P G_{7} V_{T}}$

(4)

with $Q_{\text {GLUliv }}$ the total quantity of APAP glucuronide in the liver and $C_{\text {GLUblood }}$ the concentration of APAP glucuronide in blood.

For sulfate APAP, we have:

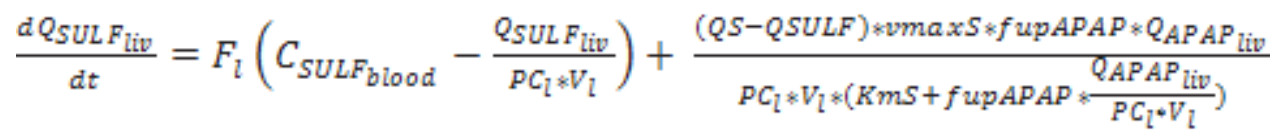

with $Q_{S U L F l i v}$ the total quantity of sulfate APAP in the liver and $C_{S U L F b l o o d}$ the concentration of APAP sulfate in blood.

Urinary excretion is assumed to occur from blood with a rate proportional to the concentration in the blood:

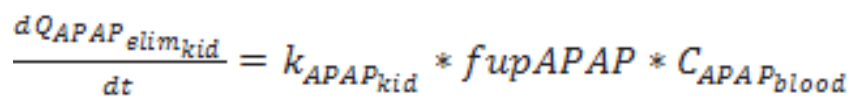

As we only disposed of data on mercapturate in the urine, not in blood, we used an equation that related directly the quantity of mercapturate eliminated in the urine and the concentration of APAP in blood: 
$\frac{d Q_{M E R_{\text {elim }}}}{d t}=k_{\text {MER Rid }} *$ fupAPAP $* C_{A P A P_{\text {blood }}}$

Some of the parameters of the PBPK model were fixed (see Table 1). For all rats, body weights $(B W$, in $\mathrm{kg})$ and urinary volume for 24 hours $(V u$, in $\mathrm{mL})$ were measured. Partitions coefficients were calculated using the algorithm by Rodgers and Rowland (2006) with Simcyp simulation software version 11.1 (Simcyp Limited, Sheffield, UK). Blood to plasma ratio equals to 1 (Naritomi et al., 2003) and protein binding values for APAP in serum is known (Bailey and Briggs, 2004). The fraction of ingested APAP entering the liver was fixed at 0.9. It corresponds to the common total amount of excreted APAP and metabolites in rat after oral absorption (Brown et al., 1979). For metabolism, $K m$ values (in $\mu$ M) for glucuronide and sulfate formations were taken from experiments with male Wistar rats by Watari et al. (1983).

All the other parameters (rate of stomach absorption, maximum velocities for metabolism, and urinary excretion rates) were estimated based on our rat in vivo data (blood and urine measurements). This estimation was performed through the maximum likelihood method. The measurement errors were assumed to be independent and log-normally distributed, with a geometric mean equal to the PBPK model predictions and a geometric standard deviation (GSD) of 1.1 (approximately 10\% error). Data likelihoods were therefore given by:

$\log (Y) \sim N\left(\log (F(X, \theta)), \sigma_{c}\right)$

where the function $F(X, \theta)$ corresponds to a PBPK model with input $\mathrm{X}$ and parameters $\theta$, and $\sigma_{c}$ is equal to 1.1. Parameters estimation and building of confidence intervals were performed using the MCSim software (Bois and Maszle, 1997).

\subsection{Human PBPK modeling and calibration}

In the human model, we focused on the kinetics of acetaminophen. The equations were the same as for rats, except for liver, with no sulfate formation limitation expected for humans, thus no resynthesis term introduced: 


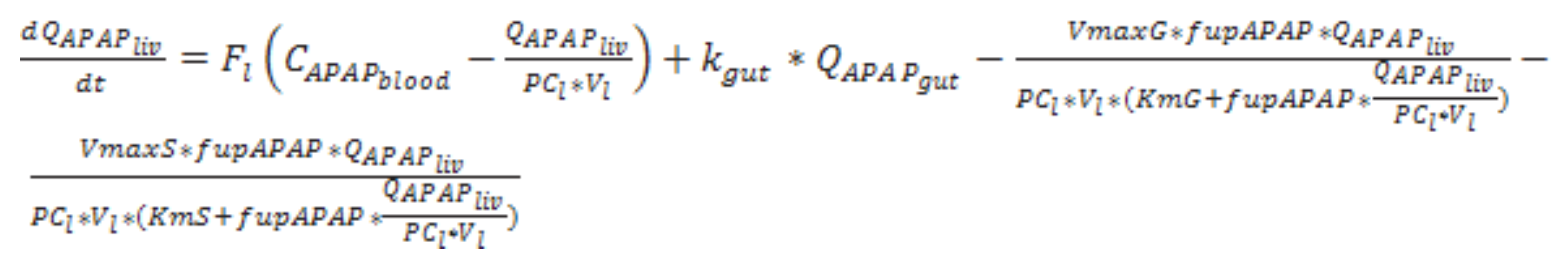

We used three ways to calibrate the human PBPK model.

The first one consisted in considering only data from methods alternative to animal testing (in vitro and in silico methods). We used two tools, ACD/Labs PhysChem Suite version 12.00 for the calculation of the octanol-water partition coefficient and $\mathrm{pKa}$, and ACD/Labs ADME Suite version 5.0 for the calculation of human intestinal absorption and fraction unbound. Then, the algorithm by Rodgers and Rowland (2006) to deduce the partition coefficients. ACD/Labs PhysChem Suite estimates the octanol-water partition coefficient $(\log \mathrm{P})$ by a structure fragment approach; it splits the structure into fragments and searches for identical fragments in the internal databases, which contains well-characterized increments for over 500 different functional groups, together with well-characterized increments for different types of carbons that are not involved in any functional group as well as well-characterized increments for over 2,000 different types of pair-wise group interactions through aliphatic, aromatic and vinylic systems. It includes two different predictive algorithms - ACD/LogP Classic and ACD/LogP GALAS. Each prediction is provided with its reliability evaluation by the means of $95 \%$ confidence intervals (ACD/LogP Classic), or Reliability Index (ACD/LogP GALAS). From the two reliable predictions of acetaminophen $\log \mathrm{P}(\mathrm{ACD} / \log \mathrm{P}$ Classic $=$ 0.34; $\mathrm{ACD} / \log \mathrm{P}$ GALAS $=0.54$ ), a consensus $\operatorname{LogP}$ value was derived equal to 0.44 . ACD/Labs PhysChem Suite was used to estimate acetaminophen $\mathrm{pKa}$; it estimates accurate acid-base ionization constants ( $\mathrm{pKa}$ values) at $25^{\circ} \mathrm{C}$ and zero ionic strength in aqueous solutions for almost any organic or inorganic structure. The accuracy of the calculations is typically better than $\pm 0.2 \mathrm{pKa}$ units except for highly complex structures or poorly characterized substituents, where the accuracy is usually within $\pm 0.5 \mathrm{pKa}$ units. The acetaminophen dissociation constants $(\mathrm{Ka})$ for the strongest acid and base ionization centers were calculated equal to $9.9( \pm 0.1)$ and $1.7(( \pm 0.5)$, respectively. The Blood Brain Barrier Penetration ACD/ADME Suite module was used to calculate the unbound fraction in plasma. The BBB module provides reliable and easily interpreted predictions of passive BBB permeation rate (expressed as LogPS constants); it calculates steady-state distribution ratio between brain tissue and plasma ( $\operatorname{LogBB})$ and unbound (i.e., pharmacologically active) 
fraction of drug in plasma and in brain tissue. The calculated unbound fraction of acetaminophen in plasma tissue was equal to 0.88 .

ACD/ADME Suite was employed for the calculation of human intestinal absorption and fraction unbound. For human intestinal absorption it predicts the effect of a compound's physicochemical properties (logKow, $\mathrm{pKa}($ acid), $\mathrm{pKa}($ base $)$ ) on the upper limit of its intestinal passive absorption via both transcellular and paracellular routes, its human jejunum permeability and its absorption rate. The model was built based on approximately 600 data points of human in vivo intestinal absorption. The acetaminophen calculated upper limit of intestinal passive absorption via transcellular and paracellular routes resulted equal to $99 \%$ and $1 \%$, respectively; the human jejunum permeability and absorption rate resulted equal to $4.68 \times 10^{-4} \mathrm{~cm} / \mathrm{s}$ and $0.032 \mathrm{~min}^{-1}$. The estimation of human oral bioavailability was obtained using the physiological-based pharmacokinetic model described and applied to acetaminophen by Paixão et al. (2012), based on in vitro and QSAR data. The fraction entering liver would be 1 for $1 \mathrm{~g}$ and 0.99 for $10 \mathrm{~g}$. In our simulation, we kept a value of 1 for all doses.

For metabolism, $\mathrm{Km}$ and $\operatorname{Vmax}$ values for glucuronide and sulfate formations were taken from experiments with cryopreserved human hepatocytes by Riches et al. (2009). As their values were expressed per number of cells, we used the conversion factor proposed by Barter et al. (2007) to have data expressed per g of liver. Excretion rate was estimated as in Rotroff et al. (2010). The rate of renal excretion was estimated by multiplying the predicted percentage of unbound acetaminophen in plasma by the normal adult human glomerular filtration rate $(111 \mathrm{ml} / \mathrm{min})$.

The second way to calibrate the human PBPK model consisted in extrapolating from rat to human. We kept the same blood to plasma ratio, partition coefficients between blood and tissues and protein binding values that were determined for rats. The fraction of ingested APAP entering the liver was also adopted from experiments on rats and fixed at 0.9. Urinary excretion rate of acetaminophen was estimated based on the estimate for rats through biometric scaling (ratio of the glomerular filteration rates of the two species (Lin, 1995)). Metabolism parameters were scaled as in Haddad et al. (1998), i.e. same Km value and Vmax scaled by $B W^{0.74}$.

The third calibration was performed by fitting available human data. Critchley et al. (2005) measured human plasma and urine concentrations of acetaminophen and its conjugates after oral administration of $20 \mathrm{mg} / \mathrm{kg}$. After 24 hours the authors found in the urine $59.9 \%$ glucuronide, $27.7 \%$ sulfate, $4.7 \%$ acetaminophen and $7.7 \%$ of other metabolites. Prior to 
adjustment, we converted these data into urine concentration and considered that all the ingested acetaminophen was in urine either as parent compound or metabolites. Critchley et al. (2005) also found respective plasmatic area under the curve (AUC) after 24hours of 83 $\mu \mathrm{g} / \mathrm{mL} / \mathrm{h}$ with maximal plasmatic concentration (Cmax) between 14.4 and $22.9 \mu \mathrm{g} / \mathrm{mL}$. Model adjustment was achieved by estimating the fraction of APAP entering liver, absorption rate and maximal velocities that would maximize the likelihood of these data (plasma AUC and Cmax and concentration of acetaminophen and metabolites in urine).

\subsection{Calibration of the in vitro dose response for HepaRG cells}

We used data on effects of acetaminophen on HepaRG cells which were available at the Joint Research Center (JRC), Ispra Italy. HepaRG cells have been shown to be a useful model to study mechanisms of acetaminophen hepatotoxicity in humans (McGill et al., 2011). The cell exposure procedure was already described in Mennecozzi et al. (2012). Briefly, a vial of cryo preserved Human Cell Line HepaRG was obtained from INSERM's laboratory U522 and a cell culture bank had been established in house at JRC. HepaRG cells were seeded at a density of $2.6 \times 10^{4}$ cells $/ \mathrm{cm}^{2}$ in the growth medium composed of Williams $\mathrm{E}$ medium supplemented with $10 \%$ FCS, 100 units $/ \mathrm{mL}$ penicillin, $100 \mu \mathrm{g} / \mathrm{mL}$ streptomycin, $5 \mu \mathrm{g} / \mathrm{mL}$ insulin, $2 \mathrm{mM}$ glutamine and $5 \times 10^{-5} \mathrm{M}$ hydrocortisone hemisuccinate, and then further culturing for 2 more weeks with the same medium supplemented with $2 \%$ DMSO in $75 \mathrm{~cm}^{2}$ culture flask. The medium was renewed every 2 to 3 days. After differentiation, HepaRG cells were detached by gentle trypsinization, then seeded at a density of $4-5 \times 10^{4} /$ well in 96 well microtiter plates (BD Biosciences) to allow the selection of hepatocyte-like populations. This procedure resulted in a higher percentage of hepatic-like cells versus biliary like epithelial cells of the HepaRG cell culture. The cells were used for testing within one week after plate seeding (Rodrigues et al., 2012). 32 exposure concentrations from $3.5 \times 10^{-8}$ to $0.01 \mathrm{M}$ were tested, with one value measured per concentration. Viability was assessed after $72 \mathrm{~h}$ of exposure through a high-content analysis approach (HCA) using Cellomics ArrayScan vTi. A 10x objective was used to collect 10 image fields per well for two fluorescence channels with the XF93 filter set. Cell count analysis was performed using the Target Activation Bioapplication v.4 from Cellomics Scan Software (Mennecozzi et al., 2012).

To analyze the effects data (cell population dynamics as a function of exposure concentration), we propose the following simple growth model: 
$\frac{d N}{d t}=-k * \max (C-N E C, 0) * N$

with $N$ the number of cells, $k$ the killing rate, $C$ the exposure concentration and $N E C$ the No Effect Concentration, i.e. the concentration threshold that a cell can be exposed to without any decrease of cell viability. In the equation, $\max$ refers to maximum value between the two terms between brackets. In the control situation, $N$ is constant as expected for HepaRG cell populations. The formalism used here is similar to the DEBtox approach used in ecotoxicology to analyze survival data (Kooijman and Bedaux, 1996), with the main difference that kinetics from the medium to the cell is neglected here. This is a pragmatic choice as we dispose only of the value after $72 \mathrm{~h}$ of exposure. As in DEBtox, the aim is to account for the time-dependence of effects, which is the only way to relate properly in vitro constant exposure concentration (in vitro cell density is not sufficient here to susbtantially metabolize acetaminophen in a $72 \mathrm{~h}$ period) and the time-varying liver concentration profiles from PBPK modelling. Parameter estimation was performed by minimizing the sum of the squared differences between the model predictions and the actual data.

\subsection{TK/TD modeling}

We coupled the PBPK models and the toxicodynamic model to calculate the expected dose response relating in vivo liver cell viability long after absorption of acetaminophen (10 days in our simulations) and the dose absorbed. To achieve this, Equation 10 was incorporated in the toxicokinetic model with liver blood acetaminophen concentration as input. We thus implicitly assumed that hepatotoxicity could be related both in vitro and in vivo to the acetaminophen concentration in the fluid in contact with the cells. As, in fact, acetaminophen hepatotoxicity is related to a minor metabolite undergoing oxidative metabolism via cytochrome P450 and produced directly and for a short time in the liver from acetaminophen (N-acetyl-p-benzoquinone imine, or NAPQI), this hypothesis seems reasonable. The three different calibrated human PBPK models were used.

\section{Results}

\subsection{PBPK modeling}

The fits of the rat PBTK model to our data are presented in Figure 2 for plasma. As for excretion, the model predicts that more than $96 \%$ of the initial amount of acetaminophen was eliminated after $24 \mathrm{~h}$ (10\% not absorbed, $41 \%$ eliminated through the bile, $45 \%$ eliminated 
through urine as sulfate conjugate (58\%), glucuronide (24\%), acetaminophen (9\%) and other metabolites (9\%)). Actual urine data showed a recovery of $45 \%$ in urine (sulfate conjugate $(56 \%)$, glucuronide $(26 \%)$, acetaminophen $(12 \%)$ and other metabolites (6\%)). Estimated parameters are given in Table 1.

The parameters' estimates for the three methods to calibrate the human PBPK are given in Table 2. The largest differences between estimates is related to maximum metabolism velocity with in vitro data largely underestimating in vivo data and for urinary excretion rate suggesting much lower renal filtration in vivo relative to acetaminophen than expected based on unbound acetaminophen in plasma. We obtained predictions of urine composition of 59\% glucuronide, $27.5 \%$ sulfate, $4.5 \%$ acetaminophen and $9 \%$ other metabolites (measured percentages were $59.9 \%$ glucuronide, $27.7 \%$ sulfate, $4.7 \%$ acetaminophen and $7.7 \%$ of other metabolites). Plasma acetaminophen area under the concentration curve at $24 \mathrm{~h}$ was close to the measured value $(80 \mu \mathrm{g} / \mathrm{mL} / \mathrm{h}$ versus between 83 and $87.6 \mu \mathrm{g} / \mathrm{mL} / \mathrm{h})$. The $C \max$ was predicted at $18.2 \mu \mathrm{g} / \mathrm{mL}$ (observed values between 14.4 and $22.9 \mu \mathrm{g} / \mathrm{mL}$ ), and the peak concentration occurs after $60 \mathrm{~min}$, as it was observed.

\section{2. $\quad$ Dose-response modeling}

Figure 3 shows the data and the model for HepaRG cells exposed to acetaminophen. We estimated a NEC of $0 \mathrm{M}$ and a value of $1.88 \mathrm{~h}^{-1}$ for $k$. The estimated EC50 is $5.1 \mathrm{mM}$, within the range of variation of published LC50 values, from 0.21 to $28.2 \mathrm{mM}$ for human hepatocytes (Fey and Wrzesinski, 2012).

Figure 4 presents the expected dose-response for the three different PBPK-TD models. Despite some high differences in some PBPK parameters values, the resulting dose response relationships do not differ substantially. The standard deviation for in vitro cell viability in control HepaRG responses was estimated at $4.9 \%$. If we calculate which dose would lead to a significant difference (at the level 0.05) compared to control situation, we obtain respectively 820,690 and $500 \mathrm{mg} / \mathrm{kg}$ for the human data-based, the rat data based and the alternative methods-based PBPK/TD models.

\section{Discussion}

4.1. Relevance of our PBPK models relative to other kinetics studies for rats and humans 
For rats, we estimated a maximum velocity for glucuronide formation of $5.3 \mu \mathrm{mol} / \mathrm{min} / \mathrm{kg}$. This is twice the value found by Watari et al. (1983) for lower exposure doses (2.76 $\mu \mathrm{mol} / \mathrm{min} / \mathrm{kg}$ ). Maximum velocity for sulfate formation at the start of the experiment was estimated at $3.5 \mu \mathrm{mol} / \mathrm{min} / \mathrm{kg}$, which is lower but close to the value from Watari et al. (1983), $4.92 \mu \mathrm{mol} / \mathrm{min} / \mathrm{kg}$. The pool of activated sulfate was estimated at a mean value of $417 \mu \mathrm{mol}$. As hypothesized, the rate of formation of new activated sulfate $(10 \mu \mathrm{mol}$ per hour) is low compared to this pool, which explains the rapid saturation (half depletion time is estimated at $95 \mathrm{~min})$. The renal clearance we found $(0.00031 \mathrm{~L} / \mathrm{min})$ is similar to the one measured by Watari et al. (1983), around $0.00035 \mathrm{~L} / \mathrm{min}$. The quantity of biliary excretion throughout time ranges from 9 to $43 \%$ after 4 hours, and from 27 to $57 \%$ at 24 hours. These ranges are in accordance with data from the literature with rats exposed to $600 \mathrm{mg} / \mathrm{kg}$ APAP (Hjelle and Klaasen, 1984), corresponding to $20-30 \%$ at 4 hours and $50 \%$ at 24 hours. We also performed kinetic simulation with our model for a low dose of exposure $(50 \mathrm{mg} / \mathrm{kg})$ to assess its ability to predict kinetics for concentrations far below those used in our experiments. We predicted that $85-95 \%$ of urinary excreted compounds would be acetaminophen sulfate, $5-15 \%$ being acetaminophen glucuronide. Around $10 \%$ of acetaminophen would be excreted into the bile. This is coherent with data measured in urine and bile (Hjelle and Klaassen, 1984; Watari et al., 1983) showing from 5 to $20 \%$ of biliary excretion at low doses. Our rat PBPK model consequently appears to be relevant relative to the data on acetaminophen kinetics available in the literature.

For humans, Rawlins et al. (1977) measured the time-course of plasma concentration for 6 volunteers after oral administration of 500, 1000 and $2000 \mathrm{mg}$ acetaminophen and Schwarz et al. (2002) followed plasma concentration after oral ingestion of $1000 \mathrm{mg}$ acetaminophen by 40 patients. They both showed an early peak in plasma concentration (in the first hour) and the half-lives were between 2.3 and 2.8 hours for the Rawlins study and above 3 hours in the Schwarz study. In our human PBPK model, calibrated on human data, we have both the early peak and a half life just below 3 hours at the doses these authors tested. The ratio between glucuronidation and sulfation at therapeutic dose $(1-1.5 \mathrm{mg})$ is estimated by the model at 2, which is realistic (Bales et al., 1984; Esteban et al., 1996). Thus, the PBPK model based on human data appears to be relevant for the purpose of our study.

\subsection{Comparison between the three calibrations of PBPK models}


The estimated parameters in Table 2 depending on the calibration method mainly differ relative to metabolism estimate. Clearly, rats and humans show qualitative and quantitative differences relative to metabolism. Mice may be a more relevant model than rats to understand the mechanisms of acetaminophen overdosing in humans (Jaeschke et al., 2011). As we found here for humans, in mice, sulfation is reduced compared to what takes place in rats and there is no sulfate depletion when toxicity occurs (Liu and Klaasen, 1996). In vitro value largely underestimated the maximum velocity, by a factor of 7 for sulfation, and of 20 for glucuronidation. This discrepancy is not surprising since the estimation of hepatic clearance with in vitro system is known to vary (Chaturvedi et al., 2001). Nevertheless, this difference is abnormally high. In the paper by Sohlenius-Sternbeck et al. (2012), an in vitro raw intrinsic clearance of $1.3 \mu \mathrm{L} / \mathrm{min} / 10^{6}$ cells was found with cryopreserved human hepatocytes, with a predicted in vivo clearance of $9.5 \mathrm{~mL} / \mathrm{min} / \mathrm{kg}$, close to the actual in vivo value (4 mL/min/kg). In our model, we used values in Riches et al. (2009), because we looked for data on sulfation and glucuronidation separately. It seems however that these values, which corresponds to $0.19 \mu \mathrm{L} / \mathrm{min} / 10^{6}$ cells, largely underestimates the in vivo metabolism rate.

Excretion is overestimated through alternative methods (based on filtration rate and unbound fraction in blood). The difference may be due to acute renal toxicity, which is characterized by cellular injury primarily confined to the proximal tubule and significant reductions in glomerular filtration rate (Blantz, 1996).

As for the other parameters, QSAR predictions performed well. The estimated absorption rate was closer to the in vivo human estimate than the one based on the extrapolation from rats. The estimated fraction unbound to protein (fup) and Kow, that have been used for calculating partition coefficients were relevant enough to obtain similar partition coefficients between all methods. Note also that the fup was estimated for plasma at 0.88 , in the range of in vitro measures of acetaminophen unbound fraction in blood from 0.68 to 0.95 (Summerfield et al., 2006; Edginton et al., 2006; Sohlenius-Sternbeck et al., 2012).

\section{3. $\quad$ Relevance of the TK/TD coupling}

In vivo cell viability is not an immediate endpoint to predict hepatotoxicity or hepatic failure. We just pointed out that a significant difference with control cell viability would be expected for an absorbed dose between 500 and $820 \mathrm{mg} / \mathrm{kg}$, depending on the model selected. These estimates are close to the usual range of human overdose, between 150 and $500 \mathrm{mg} / \mathrm{kg}$ 
(Jaeschke et al., 2011). It is important to realize that, in this paper, effects are deduced from concentration at organ level in a dynamic way (a differential equation) accounting explicitly for the time-dependence of the occurrence of adverse effects. Usually, in TK/TD approaches, in vivo and in vitro effects are related through the area under the curve (AUC) of the parent or metabolite concentration or their maximum concentration. Using a mechanistic and dynamic model to relate cell exposure concentration and cell death may provide more biological relevance. In particular, the extrapolation between different exposure durations or from one dose to repeated doses becomes straightforward. Moreover, a process of cell regeneration could easily been incorporated. It is also clear that the more data we would have for different exposure durations, the more robust the dynamic model would be. Here, data on cell viability after 24 and $48 \mathrm{~h}$ of exposure would have permitted to introduce additional parameters, accounting for instance for acetaminophen kinetics in the cells, which would have improved the relevance and the potential for extrapolation of the model. A substantial improvement may also come from a better characterization, in vitro and in vivo of the toxic metabolic pathway. The production of NAPQI is a function of both the intrinsic clearance for several CYP isozymes as well as competitive phase II metabolism. At the moment, the PBPK/PD approach we used ignores the impact of potential differences in CYP activities between the HepaRG cells and in vivo.

The dose-response curves obtained with the different calibrations of the human PBPK models did not differ substantially. The in vitro underestimation of the metabolism rate was partly compensated by the overestimation of the renal excretion. We performed additional simulations setting the renal excretion value in the PBPK model calibrated based on in vitro and in silico data to the same value as the two other calibrated models. In this case, for a given cell viability, the corresponding dose would have been divided by a factor of 3 . For instance, in this case, the dose at which significant effects on in vivo cell viability would be expected was estimated at $155 \mathrm{mg} / \mathrm{kg}$ in this case.

The application of uncertainty factors is well established in toxicological risk assessment worldwide. The key issue for decision making is to assess the confidence one can have in a toxicological data or predictions. This is even more crucial when trying to predict effects in vivo based on the integration of many components either from experimental or computational sources. A PBPK/TD model calibrated only based on alternative methods may not have the same relevance as an in vivo test, but the derivation of a confidence interval, even large, may be enough to assess protectively the safety of a compound. In the cosmetics industry, with the ban of animal testing, this would, at least, permit to market the ingredients with low expected 
concern based on rational risk estimation including a full characterisation of the inherent uncertainty. With PBPK/TD models, uncertainty should be assessed at all steps of integration and with all the sources. For instance, in the present study, quantifying the expected degree of difference between the metabolism rate estimated in vitro and the actual human one would have been of great interest. This process would be similar to the validation of Integrated Testing Strategies (ITS), in which the predictive capacity of the whole strategy may largely depend on the predictive capacity of each building block (De Wever et al., 2012). At the moment, only one in vitro toxicokinetic method is accepted at the OECD level (OECD guideline 428 for in vitro dermal absorption). It has been suggested that methods to assess in vitro protein binding, in vitro metabolism and clearance, and in vitro oral absorption should undergo reliability assessment with a small sample of compounds with properties relevant for cosmetics (Adler et al., 2011). Similarly, the same reliability assessment should also be applied to computational methods, such as the algorithms that predict partition coefficients (e.g. tissue:blood partitioning) in order to check their pertinence for the chemicals space covered by cosmetic ingredients.

\section{Acknowledgments}

The research leading to the results presented here has received funding from the European Community's Seventh Framework Program (FP7/2007-2013) and from Cosmetics Europe through the COSMOS project under grant agreement $\mathrm{n}^{\circ} 266835$. The experimental rat data have been obtained in the project ACTIVISME funded by the French ministry of ecology. The authors are very grateful to Alicia Paini who helped in the finalization of the work, so as to two anonymous reviewers who greatly helped to improve the readability of the manuscript.

\section{References}

ACD/PhysChem Suite, version 12.00. Advanced Chemistry Development, Inc., Toronto, On, Canada, www.acdlabs.com, 2012.

ACD/ADME Suite, version 5.0. Advanced Chemistry Development, Inc., Toronto, On, Canada, www.acdlabs.com, 2012.

Adler, S., Basketter, D., Creton, S., Pelkonen, O., van Benthem, J., Zuang, V., Andersen, K.E., Angers-Loustau, A., Aptula, A., Bal-Price, A., Benfenati, E., Bernauer, U., Bessems, 
J., Bois, F.Y., Boobis, A., Brandon, E., Bremer, S., Broschard, T., Casati, S., Coecke, S., Covi, R., Cronin, M., Daston, G., Dekant, W., Felter, S., Grignard, E., Gundert-Rémy, U., Heinonen, T., Kimber, I., Kleinjans, J., Komulainen, H., Kreiling, R., Kreysa, J., Batista Leite, S., Loizou, G., Maxwell, G., Mazzatorta, P., Munn, S., Pfuhler, S., Phrakonkham, P., Piersma, A., Poth, A., Prieto, P., Repetto, G., Rogiers, V., Schoeters, G., Schwarz, M., Serafimova, R., Tähti, H., Testai, E., van Delft, J., van Loveren, H., Vinken, M., Worth, A., Zaldivar, J.-M., 2011. Alternative (non-animal) methods for cosmetics testing: current status and future prospects-2010. Arch. Toxicol. 85, 367-485.

Andersen, M.E., Krewski, D., 2010. The vision of toxicity testing in the $21^{\text {st }}$ century: moving from discussion to action. Toxicol. Sci. 117, 17-24.

Bailey, D.N., Briggs, J.R., 2004. The binding of selected therapeutic drugs to human serum [alpha]-1 acid glycoprotein and to human serum albumin in vitro. Ther. Drug Monit. 26, 40-3.

Bales, J.R., Sadler, P.J., Nicholson, J.K., Timbrell, J.A., 1984. Urinary excretion of acetaminophen andits metabolites as studied by proton NMR spectroscopy. Clin. Chem. 30, 1631-1636.

Barter, Z.E., Bayliss, M.K., Beaune, P.H., Boobis, A.R., Carlile, D.J., Edwads, R.J., Houston, J.B., Lake, B.G., Lipscomb, J.C., Pelkonen, O.R., Tucker, G.T., Rostami-Hodjegan, A.R., 2007. Scaling factors for the extrapolation of in vivo metabolic drug clearance from in vitro data: reaching a consensus on values of human microsomal protein and hepatocellularity per gram of liver. Curr. Drug Metab. 8, 33-45.

Blantz, R.C., 1996. Acetaminophen: acute and chronic effects on renal function. Am. J. Kidney Dispos. 28,S3-6.

Bois, F., Maszle, D., 1997. MCSim: A simulation program, Journal of Statistical Software, 2(9):http://www.stat.ucla.edu/journals/jss/v02/i09.

Brown, R.C., Kelleher, J., Walker, B.E., Losowsky, M.S., 1979. The effect of wheat bran and pectin on paracetamol absorption in the rat. Brit. J. Nutr. 41, 455-464.

Chaturvedi, P.R., Decker, C.J., Odinecs, A., 2001. Prediction of pharmacokinetic properties using experimental approaches during early drug discovery. Curr. Opin. Chem. Biol. 5, 452-463.

Clayton, T.A., Lindon, J.C., Cloarec, O., Antti, H., Charuel, C., Hanton, G., provost, J.P., Le net, J.L., Baker, D., Walley, R.J., Everett, J.R., Nicholson, J.K. Pharmaco-metabonomic phenotyping and personalized drug treatment. Nature 440, 1073-1077.

Clewell, H. J., Tan, Y. M., Campbell, J. L., Andersen, M. E., 2008. Quantitative interpretation of human biomonitoring data. Toxicol. Appl. Pharm. 231, 122-33.

Critchley, J.A.J.H., Critchley, L.A.H., Anderson, P.J., Tomlinson, B., 2005. Differences in the single-oral-dose pharmacokinetics and urinary excretion of paracetamol and its conjugates between Hong-Kong Chinese and Caucasian subjects. J. Clin. Pharm. Ther. 30, 179-184. 
Davies, B., Morris, T., 1993. Physiological parameters in laboratory animals and humans. Pharm. Res. 10, 1093-1096.

De Wever, B., Fuchs, H.W., Gaca, M., Krul, C., Mikulowski, S., Poth, A., Roggen, E.L., Vilà, M.R., 2012. Implementation challenges for designing integrated in vitro testing strategies (ITS) aiming at reducing and replacing animal experimentation. Toxicol. in vitro 26, 526534.

Edginton, A.N., Schmitt, W., Willmann, S., 2006. Development and evaluation of a generic physiologically based pharmacokinetic model for children. Clin. Pharmacokinet. 45, 10131034.

Esteban, A., Calvo, R., Perez-Mateo, M., 1996. Paracetamol metabolism in two ethnically different Spanish populations. Eur. J. Drug Metab. Pharmacokinet. 21, 233-239.

Fey, S.J., Wrzesinski, K., 2012. Determination of drug toxicity using 3D spheroids constructed from an immortal human hepatocyte cell line. Toxicol. Sci. 127, 403-411.

Galinsky, R.E., Levy, G., 1981. Dose and time-dependent elimination of acetaminophen in rats: pharmacokinetic implications of cosubstrate depletion. J. Pharmacol. Exp. Ther. 219, 14-20.

Gubbels-van Hal, W.M.L.G., Blaauboer, B.J., Barentsen, H.M., Hoitink, M.A., Meerts, I.A.T.M., van der Hoeven, J.C.M., 2005. An alternative approach for the safety evaluation of new and existing chemicals, an exercise in integrated testing. Regul. Toxicol. Pharma. 42, 284-295.

Hjelle, J.J., Klaassen, C.D., 1984. Glucuronidation and biliary excretion of acetaminophen in rats. J. Pharmacol. Exp. Ther. 228, 407-413.

Ishii, M., Kanayama, M., Esumi, H., Ogawara, K.I., Kimura, T., Higaki, K., 2002. Pharmacokinetic analysis of factors determining elimination pathways for sulfate and glucuronide metabolites of drugs. I: Studies by in vivo constant infusion. Xenobiotica 32, 441-450.

Jaeschke, H., McGill Mitchell R., Williams, D., Ramachandran, A., 2011. Current issues with acetaminophen hepatotoxicity-a clinical relevant model to test the efficacy of natural products. Life Sci. 88, 737-745.

Kim, H.J., Rozman, P., Madhu, C., Klaassen, C.D., 1992. Homeostasis of sulfate and 3'phosphoadenosine 5'-phosphosulfate in rats after acetaminophen administration. J. Pharmacol. Exp. Ther. 261, 1015-1021.

Kooijman, S.A.L.M., Bedaux, J.J.M., 1996. The analysis of aquatic toxicity data. VU University Press, Amsterdam.

Krewski, D., Acosta, D., Andersen, M., Anderson, H., Bailar, J.C., Boekelheide, K., Brent, R., Charnley, G., Cheung, V.G., Green, S., Kelsey, K.T., Kerkvliet, N.I., Li, A.A., McCray, L., Meyer, O., Patterson, R.D., Pennie, W., Scala, R.A., Solomon, G.M., Stephens, M., Yager, 
J., Zeise, L., 2010. Toxicity testing in the $21^{\text {st }}$ century: a vision and a strategy. J. Toxicol. Environ. Health B Crit. Rev. 13, 51-138.

Lanevskij, K., Japertas, P., Didziapetris, R., Petrauskas, A., 2009. Ionization-specific prediction of blood-brain permeability. J Pharm Sci, 98, 122-134.

Lin, J.H., 1995. Species similarities and differences in pharmacokinetics. Drug. Metab. Dispos. 23, 1008-1021.

Liu, L., Klaassen, C.D., 1996. Different mechanism of saturation of acetaminophen sulfate conjugation in mice and rats. Toxicol. Appl. Pharmacol. 139, 128-134.

Louisse, J., Verwei, M., Woutersen, R.A., Blaauboer, B.J., Rietjens, I .M.C.M., 2012. Toward in vitro biomarkers for developmental toxicity and their extrapolation to the in vivo situation. Expert Opin. Drug Metab. Toxicol. 8, 11-27.

McGill, M.R., Yan, H.M., Ramachandran, A., Murray, G.J., Rollins, D.E., Jaeschke, H., 2011. HepaRG cell: a human model to study mechanisms of acetaminophen hepatotoxicity. Hepatology 53, 974-982.

Mennecozzi, M., Landesmann, B., Harris, G. A., Liska, R., Whelan M., 2011. Hepatotoxicity Screening Taking a Mode-Of-Action Approach Using HepaRG Cells and HCA. Altex Proceedings, 1/12, Proceedings of WC8, Montreal Canada 2011.

Mielke, H., Gundert-Remy, U., 2009. Bisphenol A levels in blood depend on age and exposure. Toxicol. Lett. 190, 32-40.

Mielke, H., Anger, L.T., Schug, M., Hengstler, J.G., Stahlmann, R., Gundert-Remy, U., 2011. A physiologically based toxicokinetic modeling approach to predict relevant concentratons for in vitro testing. Arch. Toxicol. 85, 555-563.

Naritomi, Y., Terashita, S., Kagayama, A., Sugiyama, Y. 2003. Utility of hepatocytes in predicting drug metabolism : comparison of hepatic intrinsic clearance in rats and humans in vivo and in vitro. Drug Metab. Dispos. 31, 580-588.

Paixão, P., Gouveia, L.F., Morais, J.A., 2012. Prediction of the human oral bioavailability by using in vitro and in silico drug related parameters in a physiologically based absorption model. Intern. J. Pharmaceutics 429, 84-98.

Péry, A.R.R., Brochot, C., Desmots, S., Boize, M., Sparfel, S., Fardel, O., 2011. Predicting in vivo gene expression in macrophages after exposure to benzo(a)oyrene based on in vitro assays and toxicokinetic/toxicodynamic models. Toxicol. Lett. 201, 8-14.

Punt, A., Schiffelers, M.-J. W.A., Horbach G.J., van de Sandt, J.M., Groothuis, G.M.M., Rietjens, I.M.C.M., Blaauboer, B.J., 2011. Evaluation of research activities and research needs to increase the impact and applicability of alternative testing strategies in risk assessment practice. Regul. Toxicol. Pharmacol. 61, 105-114. 
Rawlins, M.D., Henderson, D.B., Hijab, A.R., 1977. Pharmacokinetics of paracetamol (acetaminophen) after intravenous and oral administration. Eur. J. Clin. Pharmacol. 11, 283-286.

Riches, Z., Bloomer, J., Patel, A., Nolan, A., Coughtrie, M., 2009. Assessment of cryopreserved human hepatocytes as a model system to investigate sulfation and glucuronidation and to evaluate inhibitors of drug conjugation. Xenobiotica 39, 374-381.

Rodgers, T., Rowland, M., 2006. Physiologically based pharmacokinetic modeling 2: predicting the tissue distribution of acids, very weak bases, neutrals and zwitterions. J. Pharmacol. Sci. 95, 1238-1257.

Rodrigues, R. M., Bouhifd, M., Bories, G., Sacco, M., Gribaldo, L., Fabbri, M., Coecke, S., Whelan, M.P., 2012. Assessment of an automated in vitro basal cytotoxicity test system based on metabolically-competent cells. Toxicology in Vitro, in press.

Rotroff, D.M., Wetmore, B.A., Dix, D.J., Ferguson, S.S., Clewell, H.J., Houck, K.A., LeCluyse, E.L., Andersen, M.E., Judson, R.S., Smith, C.M., Sochaski, M.A., Kavlock, R.J., Boellmann, F., Martin, M.T., Reif, D.M., Wambaugh, J.F., Thomas, R.S., 2010. Incorporating human dosimetry and exposure into high-throughput in vitro toxicity screening. Toxicol. Sci. 117, 348-358.

Schwarz, N., Banditt, P., Gerlach, K.L., Meyer, F.P., 2002. Absorption kinetics of paracetamol are not influenced by high anxiety levels in preoperative patients. Inter. J. Clin. Pharm. Ther. 40, 419-421.

Sohlenius-Sternbeck, A.-K., Jones, C., Ferguson, D., Middleton, B.J., Projean, D., Floby, E., Bylund, J., Afzelius, L. 2012. Practical use of the regression offset approach for the prediction of in vivo intrinsic clearance from hepatocytes. Xenobiotica. Early online.

Summerfield, S.G., Stevens, A.J., Cutler, L., del Carmen Osuna, M., Hammond, B., Tang, S.P., Hersey, A., Spalding, D.J., Jeffrey, P., 2006. Improving the in vitro prediction of in vivo central nervous system penetration: integrating permeability, P-glycoprotein efflux, and free fractions in blood and brain. J. Pharmacol. Exp. Ther. 316, 1282-1290.

Watari, N., Iwai, M., Kaneniwa, N., 1983. Pharmacokinetic study of the fate of acetaminophen and its conjugates in rats. J. Pharmacokinet. Biopharm. 11, 245-272.

Yoon, M., Campbell, J.L., Andersen, M.E., Clewell, H.J., 2012. Quantitative in vitro to in vivo extrapolation of cell-based toxicity assay results. Crit. Rev. Toxicol. 42, 633-652. 


\section{Table 1}

Parameters of the rat PBPK model. Values are either from the literature or estimated based on the data we generated

\begin{tabular}{|c|c|c|c|}
\hline Body weight (kg) & $B W$ & & measured \\
\hline Urinary volume $(\mathrm{mL})$ & $V u$ & & measured \\
\hline Scaled volume of liver & $s c V l$ & 0.037 & Haddad et al., 1998 \\
\hline Scaled volume of adipose tissues & $s c V f$ & 0.07 & Haddad et al., 1998 \\
\hline Scaled volume of well perfused tissues & $s c V w p$ & 0.11 & Haddad et al., 1998 \\
\hline Scaled volume of poorly perfused tissues & $s c V p p$ & 0.723 & Haddad et al., 1998 \\
\hline Scaled volume of blood & $s c V b l$ & 0.06 & Haddad et al., 1998 \\
\hline Cardiac output (L/min/kg) & Fcard & 0.296 & Davies and Morries, 1993 \\
\hline Scaled liver blood flow & $s c F l$ & 0.25 & Haddad et al., 1998 \\
\hline Scaled adipose tissues blood flow & $s c F f$ & 0.07 & Haddad et al., 1998 \\
\hline Scaled well perfused blood flow & $s c F w p$ & 0.54 & Haddad et al., 1998 \\
\hline Scaled poorly perfused blood flow & scFpp & 0.14 & Haddad et al., 1998 \\
\hline Fraction of APAP entering liver & Frac $_{\text {ing }}$ & 0.9 & Brown et al., 1979 \\
\hline Absorption rate from gut to stomach $\left(\mathrm{min}^{-1}\right)$ & $k_{\text {gut }}$ & 0.0116 & estimated \\
\hline Liver to blood APAP partition coefficient & $P C_{l}$ & 0.774 & Rodgers and Rowland, 2006 \\
\hline $\begin{array}{l}\text { Well perfused tissues to blood APAP partition } \\
\text { coefficient }\end{array}$ & $P C_{w p}$ & 0.774 & Rodgers and Rowland, 2006 \\
\hline $\begin{array}{l}\text { Poorly perfused tissues to blood APAP partition } \\
\text { coefficient }\end{array}$ & $P C_{p p}$ & 0.66 & Rodgers and Rowland, 2006 \\
\hline Adipose tissues to blood APAP partition coefficient & $P C_{f}$ & 0.25 & Rodgers and Rowland, 2006 \\
\hline Protein binding for APAP in liver & fupAPAP & 0.75 & Ishii et al., 2002 \\
\hline Protein binding for sulfate APAP & fupSULF & 0.38 & Ishii et al., 2002 \\
\hline Protein binding for APAPglucuronide & fupGLU & 1.01 & Ishii et al., 2002 \\
\hline $\begin{array}{l}\text { Michaelis constant for APAP glucuronide formation } \\
(\mu \mathrm{M})\end{array}$ & $K m G$ & 915 & Watari et al., 1983 \\
\hline Michaelis constant for sulfate APAP formation $(\mu \mathrm{M})$ & $K m S$ & 109 & Watari et al., 1983 \\
\hline $\begin{array}{l}\text { Maximum velocity for APAP glucuronide formation } \\
(\mu \mathrm{mol} / \mathrm{min})\end{array}$ & $\operatorname{Vmax} G$ & 5.3 & estimated \\
\hline $\begin{array}{l}\text { Maximum velocity for sulfate APAP formation per } \\
\mu \mathrm{mol} \text { sulfate }(\mu \mathrm{mol} / \mathrm{min} / \mu \mathrm{mol})\end{array}$ & vmaxS & 0.00854 & estimated \\
\hline Total quantity of available sulfate $(\mu \mathrm{mol})$ & $Q S$ & 417 & estimated \\
\hline APAP urinary excretion rate (L/min) & $k_{\text {APAPkid }}$ & 0.00031 & estimated \\
\hline APAP glucuronide urinary excretion rate (L/min) & $k_{\text {GLUkid }}$ & 0.0031 & estimated \\
\hline Sulfate APAP urinary excretion rate $(\mathrm{L} / \mathrm{min})$ & $k_{\text {SULFkid }}$ & 0.024 & estimated \\
\hline Mercapturate urinary excretion rate $(\mathrm{L} / \mathrm{min})$ & $k_{\text {MERkid }}$ & 0.00028 & estimated \\
\hline APAP glucuronide biliary excretion rate (L/min) & $k_{\text {GLUbil }}$ & 0.0095 & estimated \\
\hline
\end{tabular}




\section{Table 2}

Parameters of the human PBPK model, depending on the method we used to calibrate it (only alternative methods, extrapolation from the rat model, use of human data leading to reestimation).

\begin{tabular}{|c|c|c|c|}
\hline Body weight (kg) & $B W$ & 73 & Fixed \\
\hline Urinary volume $(\mathrm{mL})$ & $V u$ & 1500 & Fixed \\
\hline Scaled volume of liver & $s c V l$ & 0.025 & Mielke and Gundert-Remy, 2009 \\
\hline Scaled volume of adipose tissues & $s c V f$ & 0.25 & Mielke and Gundert-Remy, 2009 \\
\hline Scaled volume of well perfused tissues & $s c V w p$ & 0.08 & Mielke and Gundert-Remy, 2009 \\
\hline Scaled volume of poorly perfused & $s c V p p$ & 0.06 & Mielke and Gundert-Remy, 2009 \\
\hline Cardiac output $(\mathrm{L} / \mathrm{min} / \mathrm{kg})$ & Fcard & 0.089 & Mielke and Gundert-Remy, 2009 \\
\hline Scaled liver blood flow & $s c F l$ & 0.255 & Mielke and Gundert-Remy, 2009 \\
\hline Scaled adipose tissues blood flow & $s c F f$ & 0.05 & Mielke and Gundert-Remy, 2009 \\
\hline Scaled poorly perfused blood flow & scFpp & 0.22 & Mielke and Gundert-Remy, 2009 \\
\hline Fraction of APAP entering liver & Frac $_{\text {ing }}$ & $\begin{array}{l}1 \\
0.9 \\
0.95\end{array}$ & $\begin{array}{l}\text { Paixão et al. (2012) } \\
\text { Same value as for rats } \\
\text { Re-estimated for humans. }\end{array}$ \\
\hline Absorption rate from gut to stomach $\left(\mathrm{min}^{-1}\right)$ & $k_{\text {gut }}$ & $\begin{array}{l}0.032 \\
0.0116 \\
0.025\end{array}$ & $\begin{array}{l}\text { QSAR estimate } \\
\text { Same value as for rats } \\
\text { Re-estimated for humans }\end{array}$ \\
\hline Liver to blood APAP partition coefficient & $P C_{l}$ & $\begin{array}{l}0.79 \\
0.77\end{array}$ & $\begin{array}{l}\text { QSAR estimate } \\
\text { Same value as for rats }\end{array}$ \\
\hline $\begin{array}{l}\text { Well perfused tissues to blood APAP partition } \\
\text { coefficient }\end{array}$ & $P C_{w p}$ & $\begin{array}{l}0.79 \\
0.77\end{array}$ & $\begin{array}{l}\text { QSAR estimate } \\
\text { Same value as for rats }\end{array}$ \\
\hline $\begin{array}{l}\text { Poorly perfused tissues to blood APAP partition } \\
\text { coefficient }\end{array}$ & $P C_{p p}$ & $\begin{array}{l}0.68 \\
0.66\end{array}$ & $\begin{array}{l}\text { QSAR estimate } \\
\text { Same value as for rats }\end{array}$ \\
\hline Adipose tissues to blood APAP partition coefficient & $P C_{f}$ & $\begin{array}{l}0.28 \\
0.25\end{array}$ & $\begin{array}{l}\text { QSAR estimate } \\
\text { Same value as for rats }\end{array}$ \\
\hline Protein binding for APAP in liver & fupAPAP & $\begin{array}{l}0.88 \\
0.75\end{array}$ & $\begin{array}{l}\text { QSAR estimate } \\
\text { Same value as for rats }\end{array}$ \\
\hline $\begin{array}{l}\text { Michaelis constant for APAP glucuronide formation } \\
(\mu \mathrm{M})\end{array}$ & $K m G$ & $\begin{array}{l}6000 \\
915\end{array}$ & $\begin{array}{l}\text { Riches et al., } 2009 \\
\text { Same value as for rats }\end{array}$ \\
\hline Michaelis constant for sulfate APAP formation $(\mu \mathrm{M})$ & $K m S$ & $\begin{array}{l}300 \\
109\end{array}$ & $\begin{array}{l}\text { Riches et al., } 2009 \\
\text { Same value as for rats }\end{array}$ \\
\hline $\begin{array}{l}\text { Maximum velocity for APAP glucuronide formation } \\
(\mu \mathrm{mol} / \mathrm{min} / \mathrm{kg} \text { liver })\end{array}$ & $\operatorname{Vmax} G$ & $\begin{array}{l}36 \\
106 \\
720\end{array}$ & $\begin{array}{l}\text { Riches et al., } 2009 \text {; Barter et al., } \\
2007 \\
\text { Extrapolated from rats } \\
\text { Re-estimated for humans }\end{array}$ \\
\hline $\begin{array}{l}\text { Maximum velocity for sulfate APAP formation } \\
(\mu \mathrm{mol} / \mathrm{min} / \mathrm{kg} \text { liver })\end{array}$ & $\operatorname{VmaxS}$ & $\begin{array}{l}2.9 \\
72 \\
20\end{array}$ & $\begin{array}{l}\text { Riches et al., } 2009 \text {; Barter et al., } \\
2007 \\
\text { Extrapolated from rats } \\
\text { Re-estimated for humans }\end{array}$ \\
\hline APAP urinary excretion rate $(\mathrm{L} / \mathrm{min})$ & $k_{\text {APAPkid }}$ & $\begin{array}{l}0.098 \\
0.016\end{array}$ & $\begin{array}{l}\text { Calculated } \\
\text { Scaled from rat model }\end{array}$ \\
\hline Mercapturate urinary excretion rate (L/min) & $k_{\text {MERkid }}$ & $\begin{array}{l}0 \\
0.015\end{array}$ & $\begin{array}{l}\text { Default value } \\
\text { Scaled from rat model }\end{array}$ \\
\hline
\end{tabular}




\section{Figure legends}

Fig. 1. Schematic presentation of the PBTK model used to describe the kinetics of acetaminophen and its metabolites.

Fig. 2. Kinetics of acetaminophen and its two main metabolites (glucuronide and sulfate) in rat plasma (the data points are the measured values and the line represents the prediction for an individual with a median weight and urinary volume).

Fig. 3. HepaRG cell viability as a function of acetaminophen exposure concentration. Points represent the actual data and the line represents the regression of the data with our model.

Fig. 4. Predicted in vivo cell viability as a function of dose for the three different PBPK-TD models (plain lines: PBPK models calibrated on human data; dotted lines: PBPK model extrapolated from rats; dashed lines: PBPK models calibrated on in vitro and QSAR data only). 


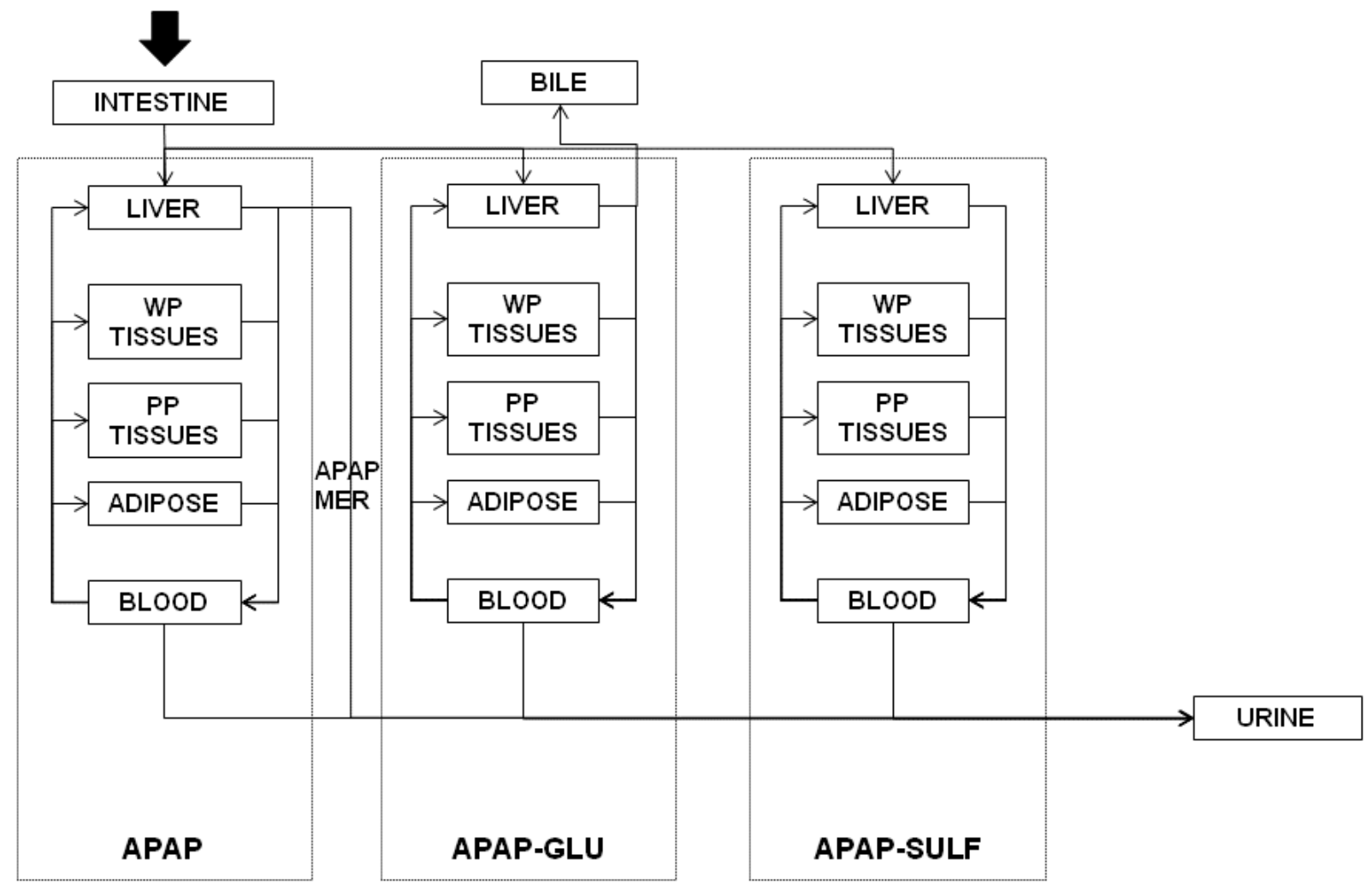

Fig. 1. 

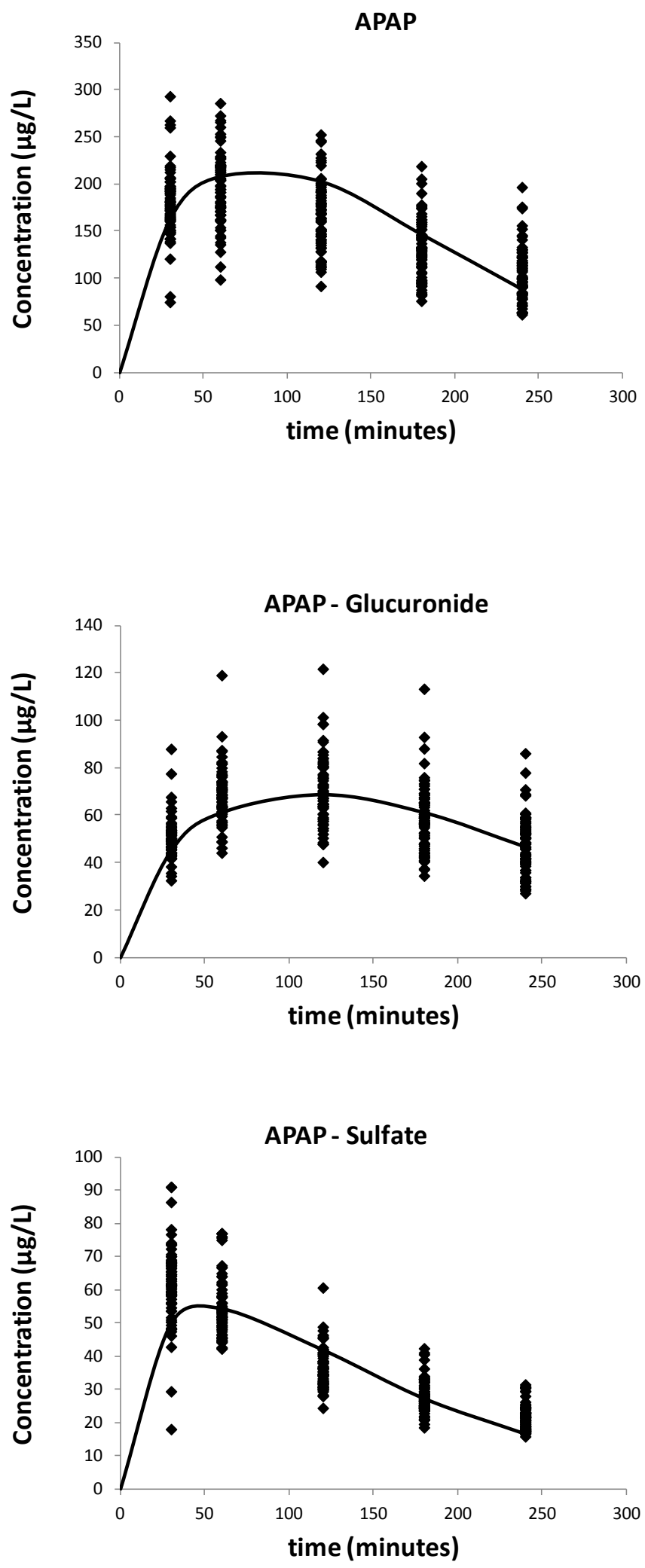

Fig. 2. 


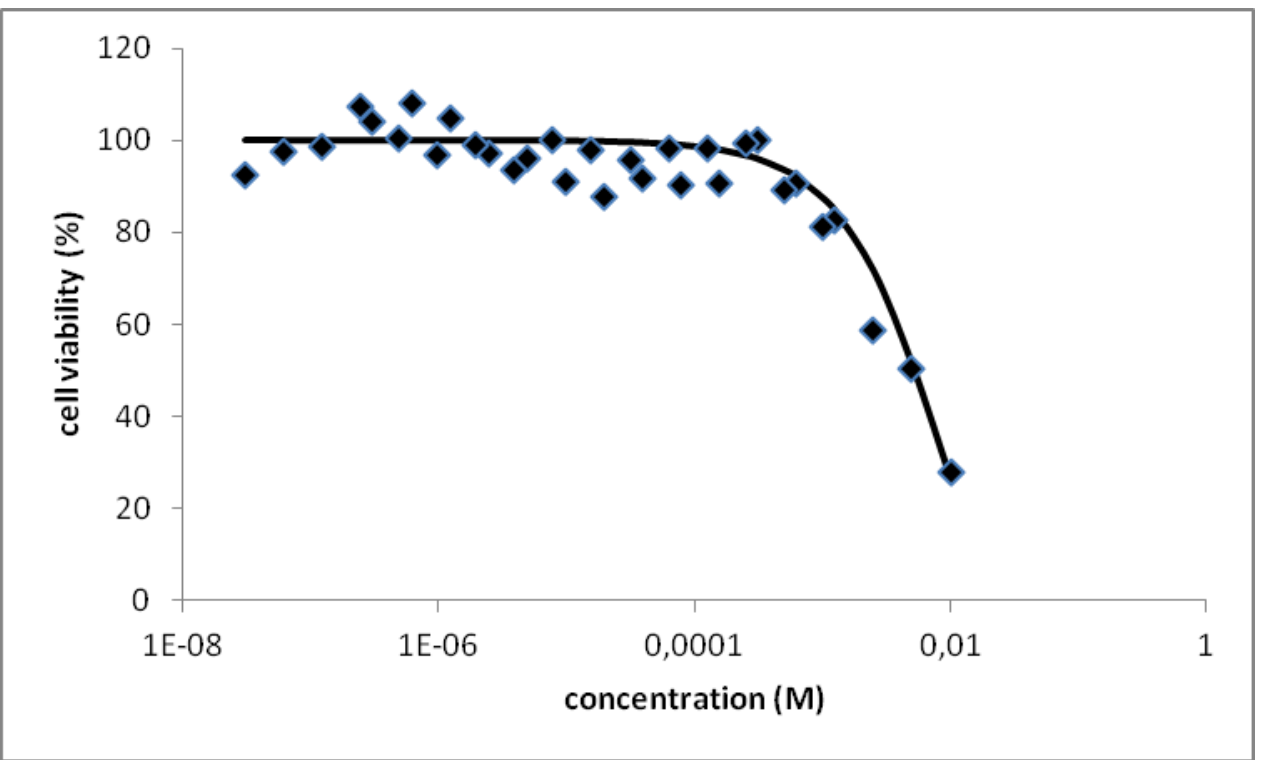

Fig. 3.

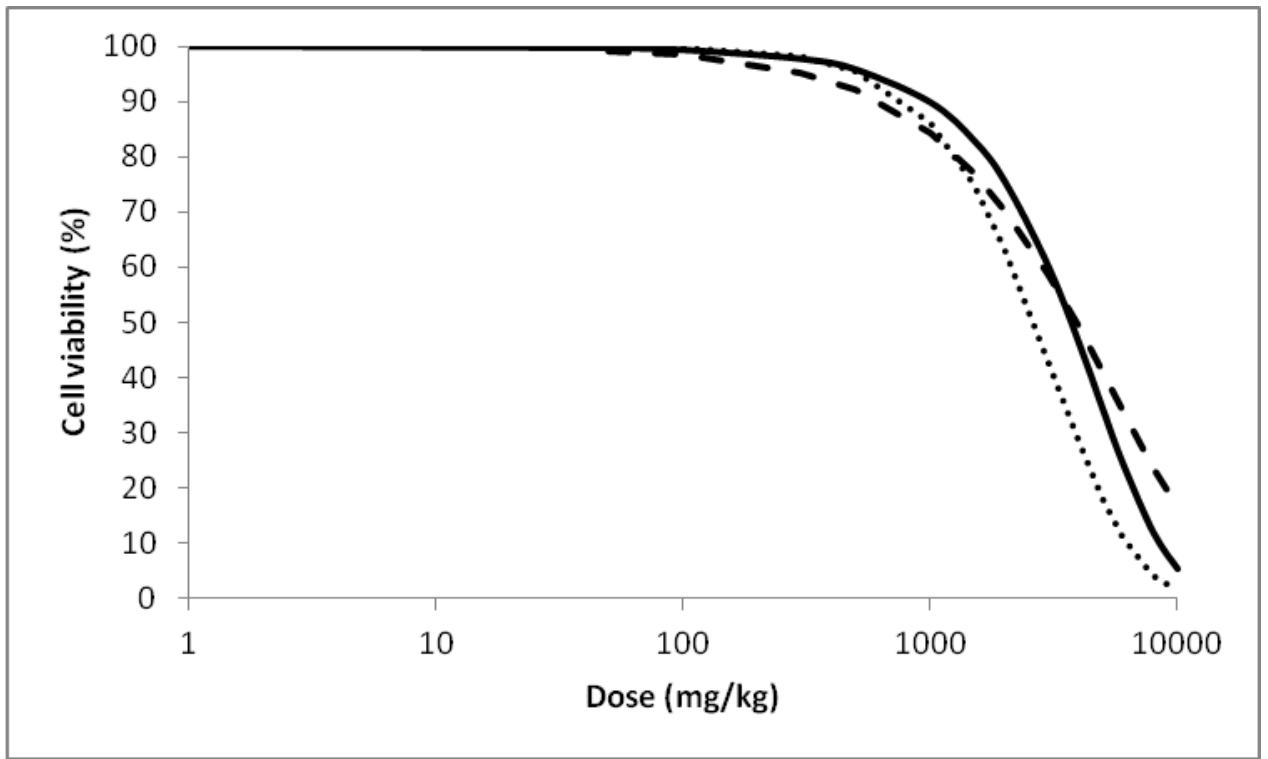

Fig. 4. 